\title{
原体照射法線量補正用多分割可変フィルタの基礎的特性
}

\author{
櫻 井 康 雄・近 藤悟・阿 部 真 治 \\ 青山裕一・成田憲彦・山口宏 \\ 小幡 康 範*・津 坂 昌 利**小山修 司* \\ 名古屋大学医学部附属病院放射線部 \\ *名古屋大学医療技術短期大学部診療放射線技術学科
}

（論文受理１994年12月 1 日）

（最終論文受理１995年 6 月17日）

(Code No. 431)

Key uords: Multi-leaf moving filter, Conformation technique, Dosimetry, Beam hardening

\section{BASIC CHARACTERISTICS OF MULTI-LEAF MOVING FILTERS TO COMPENSATE FOR ABSORBED DOSE OF A CONFORMAL BEAM}

Yasuo Sakurai, Satorl Kondoh, Shinji Abe

YuUichi Aoyama, Norihiko Narita, Hiroshi Yamaguchi

Yasuxori Obata*, Masatoshi Tsuzaka*, Shulji Korama*

Department of Radiology, Nagoya University Hospital

*Department of Radiological Technology, Nagoya University College of Medical Technology

\section{Summary}

It is already known that the absorbed dose changes due to the degree of leaf opening during irradiation with multi-leaf collimator. To compensate for this dose difference, 11 pairs of thin wedge filters correspending with multi-leaf collimators are installed in a beam shaping apparatus of a linear accelerator at Nagoya University Hospital. Basic characteristics of the filter such as filter thickness, maximum field size, the change in the beam energy and the filter factor are measured.

The usable range of the filter position and field size is limited to each other.

TPR increases to $0.96 \%$ with $6 \mathrm{MV}$ and to $0.68 \%$ with $10 \mathrm{MV} \mathrm{X}$-ray at the reference point, so the beam energy increases to about $7 \sim 10 \%$ at $6 \mathrm{MV}$ and $10 \mathrm{MV} \mathrm{X}$-ray.

Filter factors are the same at different field sizes and depths with $6 \mathrm{MV}$ and $10 \mathrm{MV} \mathrm{X}$-ray, respectively.

1.はじめに

多分割絞りを用いた原体照射法においては，絞りの開
度により深部線量に差が生じ，開度の大きな部分に比較

して開度の小さな部分では与えられる線量が減少するこ とが避けられない”。 
我々の施設では，これを補正するためそれぞれの絞り に対応して対向する楔状のフィルタを組み合わせ，絞り の開度が大きくなる場合には対向するフィル夕の重なり を大きくし合計の厚さを増して, 線量を減弱し全体の線 量を均一にすることを意図してライナックの照射口に多 分割可変フィルタを装着した（Fig. 1).

絞りの開度の変化についてその都度深部線量を測定し て可変フィル夕の厚さを決めることは煩雑で実際的では ない. 絞りの開度に対して計算により必要な可変フィル 夕の厚さが求められれば治療時に自動的にフィル夕の位 置の設定が可能となる。そのため，その計算の基礎とな る可変フィルタの位置設定值と厚さの関係, 可変フィル 夕の位置と可能な最大照射野を求め, フィルタによるビ ームのエネルギー変化, フィルタによる深部線量の変化 などの基礎的特性について今回測定を行った。

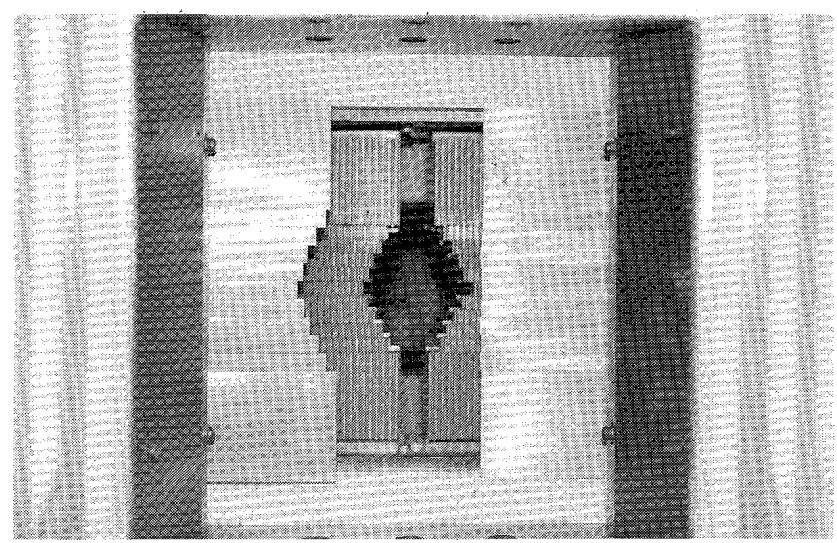

Fig. 1 The multi-leaf moving filter and multileaf collimator in the linear accelerator.

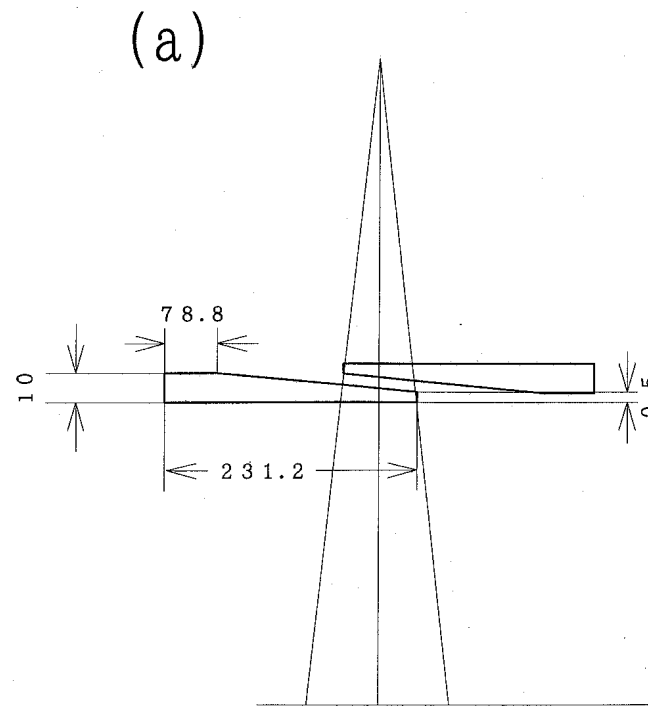

\section{2. 多分割可変フィルタシステム}

\section{1 多分割可変フィルタ}

可変フィルタはMEVATORON DX77 (シーメス社製 ライナック）の絞り部に装着され，対向した楔状で多分 割原体絞り装置と同様11対で構成される (Fig. 2).

可変フィルタの材質は黄銅（銅と垔鉛の合金, いわゆ る真鍮）で，その形状と実寸法はFig. 3 (a)に示されるご

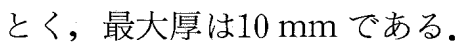

Source-axis distance (以下 SAD と略す) $100 \mathrm{~cm}$ にお

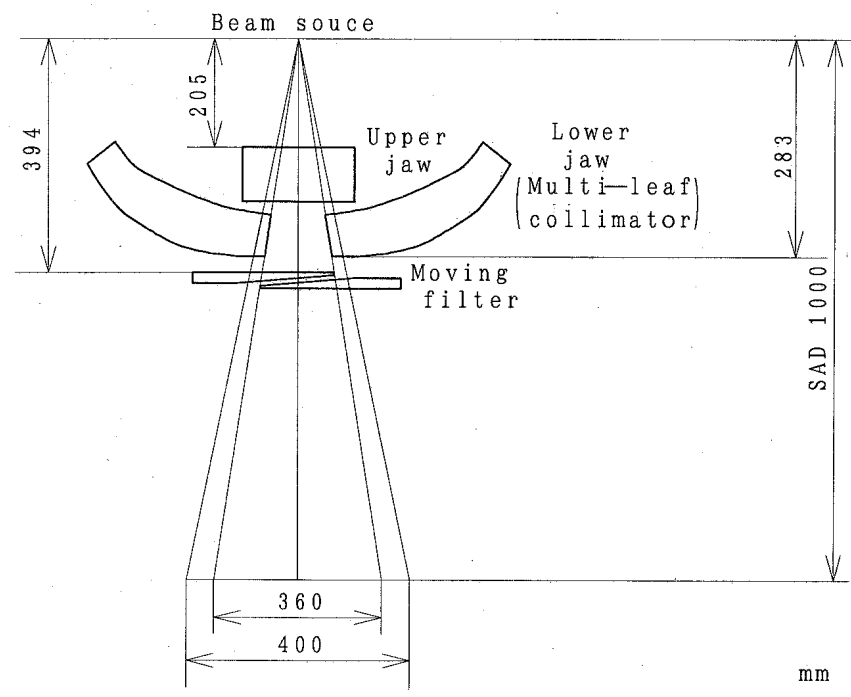

Fig. 2 Beam shaping apparatus of a linear accelerator. Geometrical relationship between the moving filter and multi-leaf collimator.

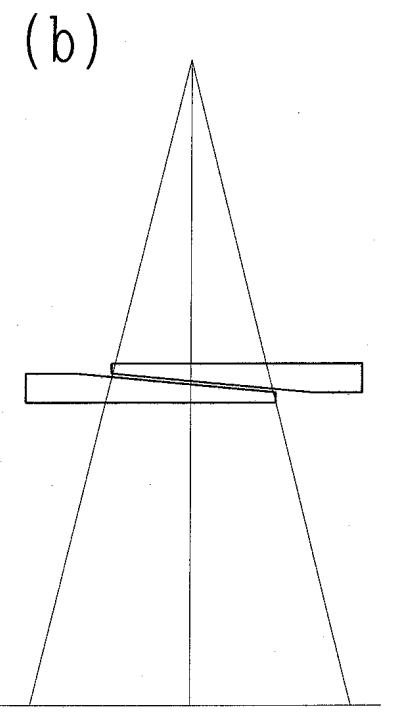

$\mathrm{m} \mathrm{m}$

Fig. 3 Schematic of the shape of the moving filter and the relationship between the filter position and the maximum field size.

(a) Slightly closed position

(b) Almost closed position 

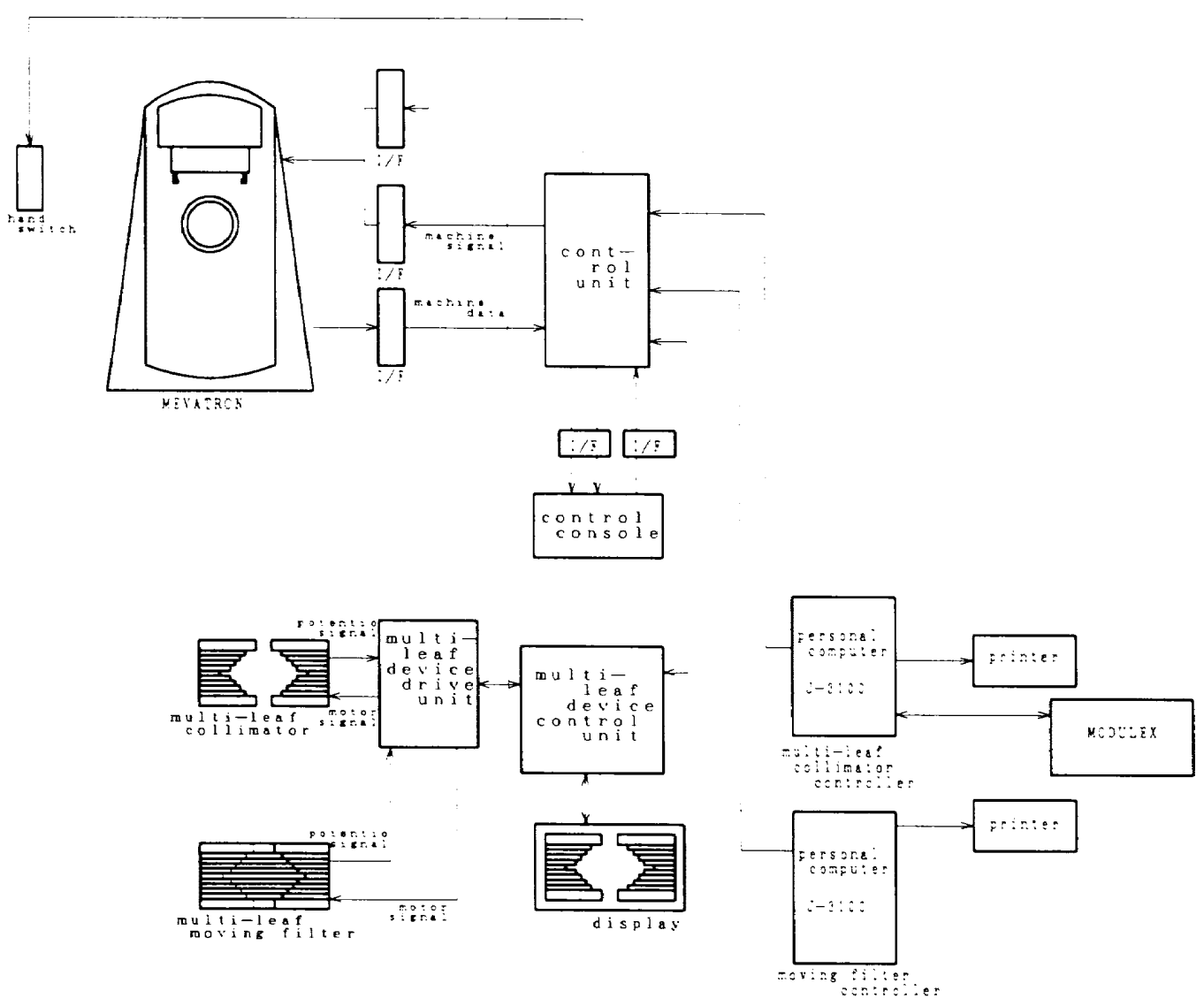

treatment room

operating room

Fig. 4 Block diagram of a linear accelerator with a moving filter and its controller.

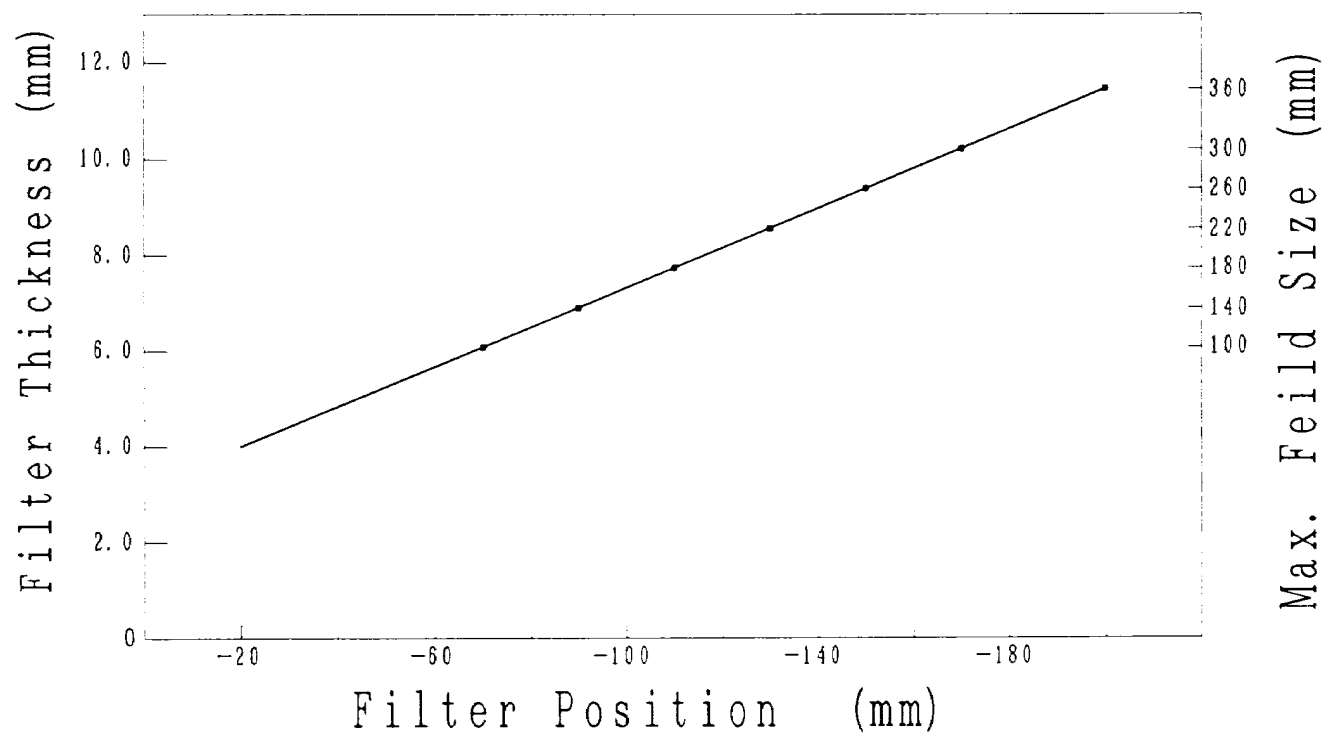

Fig. 5 Relationship between the filter position and filter thickness or the maximum field size. The usable range exists under the line. 
いて可変フィルタの開閉範囲は可変フィルタの強度の理 由からフィルタの先端が $20 \mathrm{~mm}$ に相当する分だけカッ トしてあるために, フィルタポジションはその先端がビ 一ム中心にあると -20 , 中心を越えて最大に閉じると -200 ，最大に開いた時が＋200と表示される。

\section{2 可変フィルタ制御部}

可変フィルタ11対の羽根は $\mathrm{J}-3100$ (東芝社製パーソ ナルコンピュータ) を用いてそれぞれ単独に制御され， 架台角度 2 度每に設定されたデジタルデータにもとづき 開閉制御される (Fig. 4).

可変フィルタ開度計算部とのインターフェース機能を 有し, 多分割原体絞り羽根開度量の受信, 補正フィル夕 羽根開度量の計算結果の送信，および, 補正フィルタ羽 根開度量の実際值の受信ができる。また, 補正フィル夕 開度量の実際值と設定值の比較を行い, その差が一定以 上の場合インタロック信号を出力し, 照射を停止するこ とができる。

\section{3 フィルタ厚及び最大照射野}

フィルタ位置に対するフィルタ厚と最大照射野の関係 はFig. 3 に示されるごとく, 左右のフィル夕位置が決ま ればフィルタの厚さはそれぞれの楔状フィルタの厚さの 合計となる.フィル夕が詨称的に開く場合, フィルタ位 置とフィルタ厚との関係はFig. 5 に示される. -2000 とき厚さ $11.45 \mathrm{~mm},-1100$ とき厚さ $7.72 \mathrm{~mm}$ となって いる. Fig. 3よりわかるようにお互いのフィル夕が重な つた範囲は一定の厚さとなるが，それより外方は厚さが 変化してしまうため, フィル夕の位置により設定できる 照射野の最大值が規定されてしまう。この大きさは理論 的には相詨するフィルタの位置の符号を変えて合計した ものになる筈であるが実際にはそれぞれのフィルタの先 端が SAD $100 \mathrm{~cm}$ において $20 \mathrm{~mm}$ に相当する部分が力 ットされているため幾何学照射野は $40 \mathrm{~mm}$ 狭く, フィル 夕位置が共にー2000とき $360 \mathrm{~mm},-1100$ とき $180 \mathrm{~mm}$ となっている. 又, 逆に照射野が決まるとフィルタの最 小厚が決まり，それ以上薄くしようとフィルタを広げる と中央部は予定の厚さとなるが, 照射野の両端部ではフ イルタが重ならず中央部と厚さが異なる. 結局, フィル 夕位置と照射野についてはFig. 5 に示される直線より 下の部分が有効な範囲となる．照射野が小さければフィ ルタの厚さの可変範囲は広くとれるが照射野が大きくな ればフィルタはほとんど閉じた状態で動かせないという ことになる。

\section{3. 可変フィルターによるビームエネルギーと深部線量 の变化}

\section{1 測定装置}

検出器は0.6 cc 指頭型電離箱(応用技研 C - 110 , CAPINTEC PR-06 C), 平行平板型電離箱(CAPINTEC
PS-033）を使用し，ファントムはポリスチレンを用い た。

\subsection{Tissue-peak ratio の測定によるエネルギーの 変化}

フィルタ全閉状態わよび全開状態におけるtissuepeak ratio (以下 TPR と略す) を測定し，それぞれX線 エネルギーは吸収線量の標準測定法”に示される次式を 用いて計算した。

$\overline{\mathrm{TPR}}=\mathrm{TPR}(20,10 \times 10) / \mathrm{TPR}(10,10 \times 10)$

$$
\lambda=-778.93+3660.7 \overline{\mathrm{TPR}}-5737.0 \overline{\mathrm{TPR}}^{2}
$$$$
+3015.0 \overline{\mathrm{TPR}}^{3}
$$

$\lambda^{\prime}=0.5493 \exp \left(0.1787 \mathrm{~d}_{0.7}\right)$

まず，6 MVX線のフィルタ有無による TPR 測定の 結果はFig. 6 (a)に示すごとくでフィルタなしの場合, $\operatorname{TPR}(10,10 \times 10)=0.782, \operatorname{TPR}(20,10 \times 10)=$ $0.528, \overline{\mathrm{TPR}}=0.675$ となり $\lambda=5.4(\mathrm{MV}), \lambda^{\prime}=5.9(\mathrm{MV})$ であった。

フィルタ有りの場合

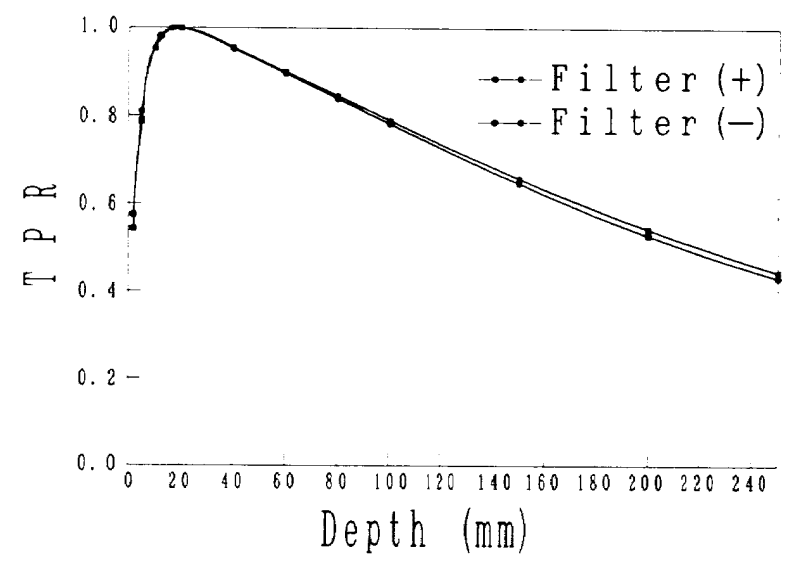

(a)

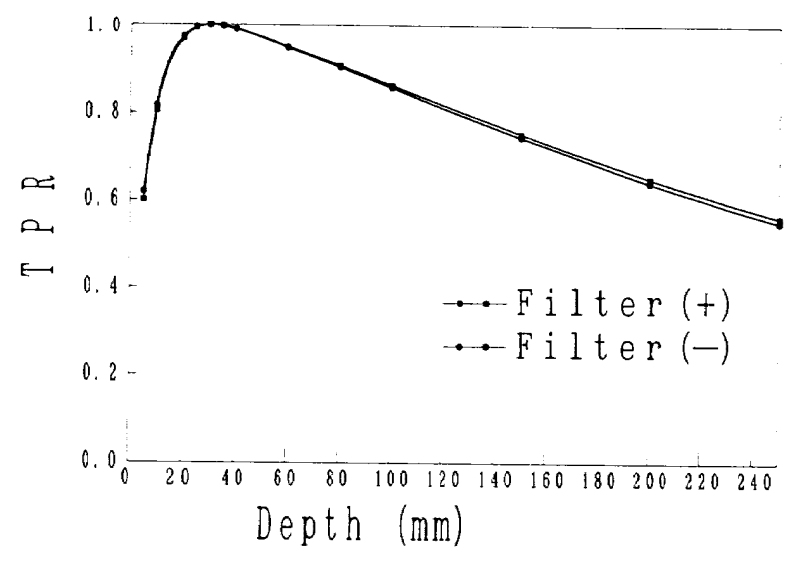

(b)

Fig. 6 Comparison of TPR for an open field (filter position: +200 ) and the filtered field (filter position: -200 ) at a field size of $10 \times 10 \mathrm{~cm}$.
(a) $6 \mathrm{MV} \mathrm{X}$-ray
(b) $10 \mathrm{MV}$ X-ray 
$\lambda=5.8(\mathrm{MV}), \lambda^{\prime}=6.3(\mathrm{MV})$ となり，フィルタを入 れることにより $\lambda: 7.4 \%, \lambda ': 6.8 \%, \mathrm{X}$ 線エネルギー が高くなった.また，10 MVX線の結果はFig. $6(\mathrm{~b}) に$ 示 した.

フィルタなしの場合, $\lambda=11.23\left(\mathrm{MV}^{\prime}\right), \lambda^{\prime}=$ $12.62(\mathrm{MV})$ フィルタ有りの場合, $\lambda=12.09(\mathrm{MV}), \lambda^{\prime}=$ 13.83 (MV) で同様に $\Lambda: 7.7 \%, \lambda ': 9.6 \%$ X線エネル ギーの上昇がみられた。

\section{3 フィルタによる深部線量の変化}

照射野 $5 \times 10 \mathrm{~cm}, 10 \times 10 \mathrm{~cm}, 15 \times 10 \mathrm{~cm}$ それぞれに

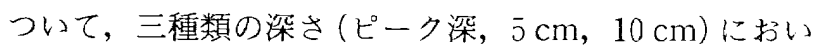
てフィルタの補正係数を测定した。

Fig. 7 に照射野 $10 \times 10 \mathrm{~cm}$, 深さ $5 \mathrm{~cm}, 6 \mathrm{MV}$ と $10 \mathrm{MV}$ のエネルギーで測定した結果を示す。フィルタの入らな い状態(フィルタ位置＋200）の線量を1として正規化す ると，6MV，10 MV，そ机ぞれ，他の照射野 $5 \times 10$ $\mathrm{cm}, 15 \times 10 \mathrm{~cm}$, 他の深さピーク深 (6 MV: $1.8 \mathrm{~cm}, 10$ $M V: 3.0 \mathrm{~cm}), 10 \mathrm{~cm}$ 测定結果も若平ばらつきがあるも のの照射野 $10 \times 10 \mathrm{~cm}$, 深さ $5 \mathrm{~cm}$ のものとほほ同じであ った.

\section{4. 考察}

可変フィルタの制御は現段階のソフトで任照射野の開 度により決定され, フィルタの先端と対側のコリメータ の開度の位置を一致させることは簡単に設定できるが, これで補正されるのはある限定された範围に留まり', 実際においては同じ照射野開度であっても他のリーフの 開度による散乱線の影響は種々様々でありより高次の制 御が必要と考えられる。

可変フィルタの性質上, フィルタ位置と照射野それぞ れ一方を決めると他方に限界があることがわかった。し かし, 一般に照射野による線量変化は小照射野領域で激

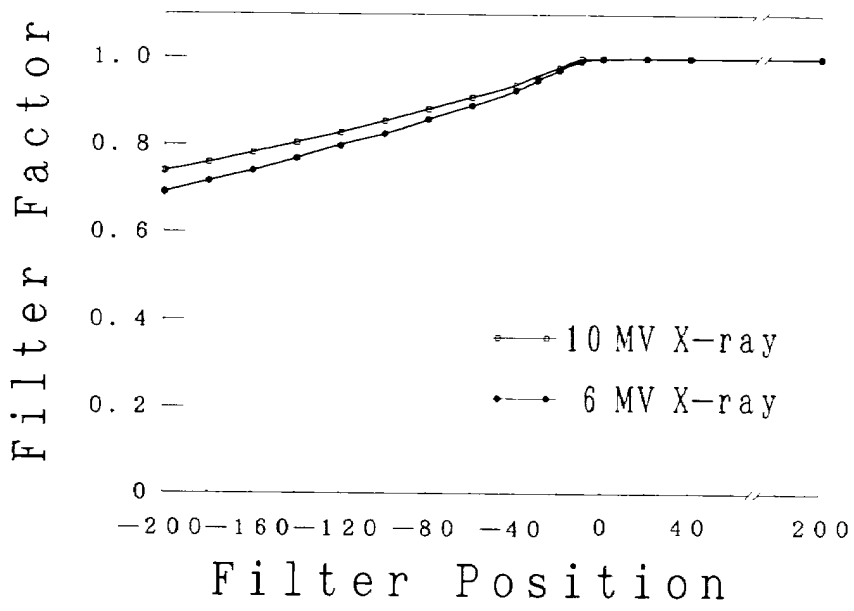

Fig. 7 Changes in the filter factor with the filter position at a field of $10 \times 10 \mathrm{~cm}$ and depth $5 \mathrm{~cm}$
しく照射野が大きくなるにつれ緩やかになるためリーフ 開度の大きな領域において可変フィルタの制御に破綻を きたすようなことは少ないと考えられる。

種々の報告にあるように今実験においてもフィルタの 挿入により TPR の変化がみられた4)-81.フィル夕を用い ることにより線質が若干硬化したためと考えられる。

可変フィルタの挿入による TPRの変化は深さ $10 \mathrm{~cm}$

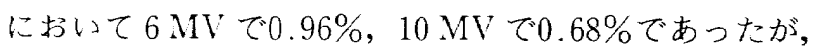
その差がたとえ僅かであったとしてもそのまま投与量の 誤差となる。本装置のフィル夕は可変であるため TPR もその厚さにより変化すると考えられるがすべてのフィ ルタポジションに対するTPRを求めることは困難であ る.

フィルタによる深部線量の変化は $6 \mathrm{MV}, 10 \mathrm{MV}$ のそ れぞれで照射野, 深さを変化させても一致しているので, 可変フィル夕の補正係数はそれぞれ照射野 $10 \times 10 \mathrm{~cm}$, 深さ $5 \mathrm{~cm}$ のデータで代表できると考えられる。フィル タポジションー40〜0でフィルタファクタの変化が単調 でなくなっているが，これはフィルタの設定範囲外で照 射野内にフィルタが均一にかかってないためであると考 えられる。

植田の報告"によれば比較的規則的に絞りの開度が階 段状に変化した照射野で $6 \mathrm{MVX}$ 線において梁部線量 の差は $5 \%$ 以内，極端に照射野幅を変化させた照射野で 10\%以内であるから可変フィルタの使用により照射野内 の線量変化注補正可能である.

今回可変フィルタの基礎的特性を測定したが多分割原 体照射の線量の不均一性の原因は二つに分けられる。一 つは回転照射のため体輪郭の前後径, 左右径に差があり 深さが変化すること, もう一つは絞りの開度により線量 に差が出ることである。

可変フィルタではこの両者の補正を考える必要があり， それぞれは全く独立なので，今後，それぞれ個別に補正 の方法を決め，最終的には統合して補正をすることが必 要になる。

\section{5. 結語}

可変フィルタを使用するにあたり，可変フィルタの制 御可能範囲, 基礎的なビームのエネルギー変化およびフ イルタファクタを測定した。

1）可変フィルタ位置と最大可能照射野には,一方を決 めると他方に限界が生じるが，一般に照射野が大きい場 合フィルタを厚くするように設定されるため制御に破綻 をきたすことは少ない。

2) 可変フィルタの使用により,最大フィル夕厚でエネ ルギーは $6 \mathrm{MVX}$ X線, $10 \mathrm{MVX}$ X線で6.8〜9.6\%高くな り,TPR の変化は深さが増加するに連れ大きくなるが深 さ10 cm においてそれぞれ $1 \%$ 以下であった。 
3）可変フィル夕による深部線量の変化はそれぞれ6 MV，10 MV X 線のエネルギーでは照射野，深さを変化 させても一致していた.

本研究は文部省科学研究費補助金一般研究 (C)（課題番号 006670915)の援助を受けた。なお，本論文の要旨は第51回日 本放射線技術学会総会学術大会 (1995年4月, 名古屋) に招い て発表した。

\section{参考文献}

1）植田俊男：原体照射法の技術と応用，日放技学誌， 32 (3)，217-248，(1976).

2）日本医学放射線学会物理部会編：放射線治療におけ る高エネルギーX線っよび電子線の吸収線量の標準 測定法，通商産業研究社，東京 (1986).

3) Kobayashi H, Sakuma S, Kaii O, et al.: Computerassisted conformation radiotherapy with a variable thickness multi-leaf filter, Int. J. Radiation Oncology Biol. Phys., 16(6), 1631-1635,
(1989).

4) Wilfred Sewchand, Faiz M. Khan, Jeffrey Williamson, : Variations in depth-dose data between open and wedge fields for 4-MV X-rays., Radiol ogy, 127, 789-792, (1978).

5）北海道部会治療専門委員会：4MV 直線加速器 $\mathrm{X}$ 線 エネルギーの検討（第2 報）ウェッジフィルタが線 質に及ぼす影響，日放技学誌，42(6)，770， (1986).

6) Fred G. Abrath, James A. Purdy, : Wedge design and dosimetry for 25-MV X-ray's., Radiology, 136, 757-762, (1980).

7) Patomäki LK, Kiuru A: Depth dose distributions in wedge fields of $\mathrm{Co}^{-} 60$ beams., Strahlentherapie, 147, 611-618, (1974).

8）中田 学, 野原弘基, 湯川 鋀, 他：補償フィル夕 を用いた場合の深部線量, 日放技学誌, 45(1), 1622, (1989). 